\title{
PENGARUH TEPUNG ILES-ILES KUNING (Amorphophallus oncophyllus PRAIN) UNTUK MENCEGAH PENINGKATAN KADAR TRIGLISERIDA PADA TIKUS PUTIH (Rattus norvegicus) DENGAN DIET ATEROGENIK
}

\author{
Nurdiana $^{\star \bowtie}$, Laksmi Karunia Tanuwijaya** Andina Devi Arvita ${ }^{* \star *}$
}

\begin{abstract}
Abstrak
Penyakit jantung merupakan penyebab kematian nomor satu di dunia. Pada penderita penyakit jantung kadar trigliserida darah cenderung lebih tinggi dari normal. Tepung iles-iles kuning merupakan terapi alternatif yang diduga dapat mengatasi penyakit degeneratif ini. Tujuan penelitian ini untuk mengetahui pengaruh tepung iles-iles kuning untuk mencegah peningkatan kadar trigliserida tikus yang diberi diet aterogenik. Penelitian ini menggunakan true experimental randomized post-test only design. Penelitian dilakukan selama 8 minggu dengan 5 kelompok yang masing-masing terdiri dari 5 ekor yaitu kelompok P0 (diet normal), P1 (diet aterogenik), P2 (diet aterogenik + tepung iles-iles kuning 0,13 g/ekor/hari), P3 (diet aterogenik + tepung iles-iles kuning 0,30 g/ekor/hari), P4 (diet aterogenik + tepung iles-iles kuning 0,60 g/ekor/hari). Variabel yang diukur adalah kadar trigliserida darah dengan menggunakan metode semi automatic (end point). Analisis data menggunakan oneway ANOVA. Hasil penelitian menunjukkan pemberian tepung iles-iles kuning dosis $0,13 \mathrm{~g} / \mathrm{ekor} / \mathrm{hari}$ tidak efektif dalam mencegah peningkatan kadar trigliserida tikus, sedangkan pemberian tepung iles-les kuning dengan dosis 0,30 dan 0,60 g/ekor/hari merupakan dosis yang efektif dalam mencegah peningkatan kadar trigliserida tikus. Kelompok P1 menunjukkan tidak adanya perbedaan yang signifikan dengan kelompok perlakuan yang diberikan tepung iles-iles kuning. Analisis kadar trigliserida menunjukkan bahwa perbedaan kadar trigliserida pada masing-masing kelompok berbeda signifikan $(p=0,017)$. Jadi dapat disimpulkan bahwa pada kelompok P2 pemberian tepung iles-iles kuning sebesar $0,13 \mathrm{~g}$ tidak berpengaruh, sedangkan pada kelompok $\mathrm{P} 3$ dan $\mathrm{P} 4$ pemberian tepung iles-iles kuning sebesar $0,30 \mathrm{~g}$ dan $0,60 \mathrm{~g}$ berpengaruh terhadap pencegahan peningkatan kadar trigliserida tikus yang diberi diet aterogenik.
\end{abstract}

Kata kunci: diet aterogenik, kadar trigliserida, penyakit jantung, tepung iles-iles kuning

\section{THE EFFECT OF ELEPHANT YAM (Amorphophallus oncophyllus PRAIN) FLOUR TO PREVENT ELEVATED LEVELS OF TRIGLYCERIDES IN ATHEROGENIC FED RAT (Rattus norvegicus)}

\begin{abstract}
Abstrack
Heart disease is the first reason of death in the world. Blood triglyceride levels in people with heart disease tend to be higher than normal. Elephant yam flour is an alternative therapy that could overcome degenerative diseases such as heart disease. The aim of this study is to determine the effect of elephant yam flour to prevent elevated levels of triglycerides in rat that fed with atherogenic diet. This study is used randomized experimental design post-test only and conducted in 8-week with 5 groups each consisting of 5 rats. The groups were P0 (normal diet), P1 (atherogenic diet), P2 (atherogenic diet + elephant yam flour 0.13 $\mathrm{g} / \mathrm{day}$ ), P3 (atherogenic diet + elephant yam flour $0.30 \mathrm{~g} /$ day), P4 (atherogenic diet + elephant yam flour 0.60 g/day). Blood triglyceride levels were measured by semi-automatic method (end point). The data were analysed using oneway ANOVA and the results showed that elephant yam flour dose of $0.13 \mathrm{~g} / \mathrm{day}$ was not effective to prevent elevated triglyceride levels in rat, whereas elephant yam flour dose of 0.30 and 0.60 g/day were effective to prevent elevated triglyceride level in rat. In P1 group revealed no significant differences compared with treatment groups that were given elephant yam flour. Analysis of triglyceride levels showed that the triglyceride levels in each group differ significantly $(p=0.017)$. It can be concluded that elephant yam flour dose of $0.13 \mathrm{~g}$ had no effect, while elephant yam flour dose of 0.30 and 0.60 were effective to prevent elevated triglycerides levels in rat that were fed with atherogenic diet. Keywords: atherogenic diet, CHD, elephant yam flour, triglyceride levels

* Laboratorium Farmakologi, FK UB

${ }^{* *}$ Program Studi Ilmu Gizi, FK UB
\end{abstract}

${ }^{凶}$ E-mail: farmakodes@gmail.com 


\section{Pendahuluan}

Saat ini, telah terjadi pergeseran pola penyakit penyebab mortalitas dan morbiditas di kalangan masyarakat, ditandai dengan perubahan pola penyakit infeksi menjadi penyakit degeneratif dan metabolik. Kecenderungan kenaikan angka kematian yang disebabkan oleh penyakit kardiovaskuler, hipertensi, stroke, kolesterol, dan diabetes semakin tinggi. Hal tersebut tidak semata-mata akibat usia lanjut, tetapi juga menyerang orang-orang yang usianya lebih muda. Salah satu faktor yang mungkin menjadi penyebabnya adalah gaya hidup (life style), mulai dari pola makan yang tidak sehat sampai kurangnya aktivitas olahraga. Pola makan yang tidak sehat antara lain diet tinggi lemak dan karbohidrat, rendahnya konsumsi makanan dengan kandungan serat. $^{1}$

Penyakit jantung merupakan penyebab kematian nomor satu di dunia. Pada tahun 1999 sedikitnya 55,9 juta atau setara dengan $30,3 \%$ kematian di seluruh dunia disebabkan oleh penyakit jantung. Sebanyak $60 \%$ dari seluruh penyebab kematian penyakit jantung adalah penyakit jantung koroner (PJK). Di Indonesia, penyakit jantung juga cenderung meningkat sebagai penyebab kematian. ${ }^{2}$ Sensus nasional tahun 2001 menunjukkan bahwa kematian karena penyakit kardiovaskuler termasuk penyakit jantung koroner adalah sebesar $26,4 \%$, dan sampai dengan saat ini PJK juga merupakan penyebab utama kematian dini pada sekitar $40 \%$ dari sebab kematian laki-laki usia menengah. ${ }^{3}$

PJK ialah penyakit jantung yang terutama disebabkan karena penyempitan arteri koronaria akibat proses aterosklerosis. $^{2} \quad$ Aterosklerosis adalah pengerasan dan penebalan dinding pembuluh darah arteri yang terjadi karena proses pengendapan lemak, kompleks karbohidrat, dan produk darah, jaringan ikat dan kalsium. Salah satu faktor risiko aterosklerosis utama adalah dislipidemia. ${ }^{4}$

Dislipidemia adalah gangguan atau perubahan pada kadar lemak dalam darah. Gangguan itu dapat berupa peningkatan kadar total kolesterol atau hiperkolesterolemia, penurunan kadar high density lipoprotein (HDL), peningkatan kadar low density lipoprotein (LDL), atau peningkatan kadar trigliserida dalam darah (hipertrigliserida). ${ }^{5}$

Makin banyaknya jumlah pengidap penyakit terkait dislipidemia dalam darah, membuat biaya yang dibutuhkan untuk pengobatan dan perawatan ikut membengkak. Harga pengobatan yang tidak terjangkau untuk semua kalangan dapat menyebabkan angka kematian akibat jantung koroner sangat tinggi. Maka diperlukan pengobatan alternatif lain yang dapat diambil dari bahan alam yang tersedia di sekitar kita. Serat lebih banyak digunakan dan direkomendasikan untuk mencegah terjadinya kejadian dislipidemia. Pemberian serat dengan viskositas yang tinggi lebih efektif menurunkan risiko kejadian dislipidemia daripada pemberian serat dengan viskositas rendah. Berdasarkan sifat kelarutan serat, serat yang mudah larut air dapat menghambat metabolisme asam lemak darah sehingga trigliserida dalam darah dapat dihambat. Semakin banyak serat yang dikonsumsi, maka semakin sedikit asam lemak yang diserap, sehingga pada akhirnya kadar trigliserida darah akan menurun. ${ }^{6}$

Jenis serat larut air bermacam-macam, salah satunya adalah glukomanan. Glukomanan adalah polisakarida dari jenis hemiselulosa yang terdiri dari ikatan rantai galaktosa, glukosa, dan mannose. Glukomanan banyak terdapat dalam tanaman konjakiles-iles (Amorphophalus muelleri Blume) (sekitar 64\%). Konjak glukomanan merupakan serat alam kental yang paling mudah larut dan membentuk 
larutan yang sangat kental. ${ }^{7}$ Kandungan glukomanan umbi iles-iles bervariasi tergantung kepada spesiesnya, dengan kisaran kandungan glukomanan antara 5$65 \%$. Salah satu jenis iles-iles yang mempunyai kandungan glukomanan tinggi adalah iles-iles kuning (Amorphophallus oncophyllus Prain) yaitu $65 \%$, sedangkan jenis lain yang mengandung glukomanan dalam jumlah cukup tinggi adalah iles-iles putih (Variabilis blume). ${ }^{8}$

lles-iles merupakan tanaman umbiumbian yang memiliki potensi ekonomi tinggi, namun saat ini masih tumbuh secara liar dan belum banyak didayagunakan. Tanaman iles-iles (Amorphophallus) sebagai sumber zat makanan yang berserat tinggi yang merupakan komoditi yang memiliki potensi untuk dikembangkan karena banyak diekspor ke berbagai negara. Tumbuhan iles-iles dapat menjadi bahan baku untuk makanan diet dan memiliki kadar serat pangan tinggi juga membantu melancarkan pencernaan. Serat larut air pada tepung ilesiles dapat dipakai sebagai pangan fungsional yang bermanfaat untuk menekan peningkatan kadar trigliserida darah karena dapat menghambat pembentukan asam lemak, sehingga pembentukan kadar trigliserida darah dapat dihambat.

Oleh karena itu perlu dilakukan kajian lebih lanjut melalu penelitian eksperimental laboratorium untuk mengetahui dan membuktikan peranan tepung iles-iles kuning (Amorphophallus oncophyllus Prain) dalam menurunkan kadar trigliserida pada tikus yang diberikan diet aterogenik.

\section{Bahan dan Metode}

Desain Penelitian:

Rancangan penelitian ini adalah penelitian true eksperimental dengan menggunakan randomized post test-only control group design, yang akan dilakukan dengan rancangan acak lengkap karena menggunakan hewan coba, bahan ransum, tempat percobaan, dan bahan penelitian lainnya yang homogen. ${ }^{9}$ Kemudian hewan coba yaitu tikus dibagi menjadi 5 kelompok, yaitu: P0 (diet normal), P1 (diet aterogenik), P2 (diet aterogenik $+0,16 \mathrm{~g}$ tepung iles-iles kuning), P3 (diet aterogenik $+0,32 \mathrm{~g}$ tepung iles-iles kuning), P4 (diet aterogenik $+0,64 \mathrm{~g}$ tepung iles-iles kuning). Penggunaan dosis didasarkan akan kebutuhan serat manusia yang kemudian dikonversikan ke kebutuhan serat hewan coba Perlakuan diberikan selama 8 minggu, setelah itu dilakukan pengambilan darah tikus dan penghitungan kadar trigliserida darah tikus.

Perlakuan Tepung lles-iles Kuning:

Tepung yang digunakan adalah yang berasal dari iles-iles kuning. Tepung iles-iles kuning dicampur dengan air dengan perbandingan 1:4, lalu diberikan pada tikus melalui spuit yang ujungnya dipasangi alat sonde yang bisa melewati rongga mulut, esophagus, hingga lambung.

\section{Pemeriksaan Kadar Trigliserida:}

Kadar trigliserida darah pada tikus diperiksa dengan menggunakan metode semi automatic (end point) di Laboratorium Klinik Kawi 31 Malang.

Analisis Data:

Data hasil penelitian dianalisis dengan metode one way ANOVA untuk menguji ratarata pada kelompok P0, P1, P2, P3, dan P4. Penelitian dianggap bermakna atau berbeda signifikan jika nilai $p<a$, dengan tingkat kepercayaan $95 \%(a=0,05)$. Jika terdapat perbedaan yang bermakna antara kelompok perlakuan, dilanjutkan dengan uji Tukey untuk melihat perbedaan makna antar kelompok. 
Hasil

Kadar trigliserida darah tikus pada masing-masing kelompok diketahui setelah dilakukan uji laboratorium menggunakan metode semi automatic (end point). Ratarata kadar trigliserida pada kelima kelompok ditampilkankan pada Gambar 1.

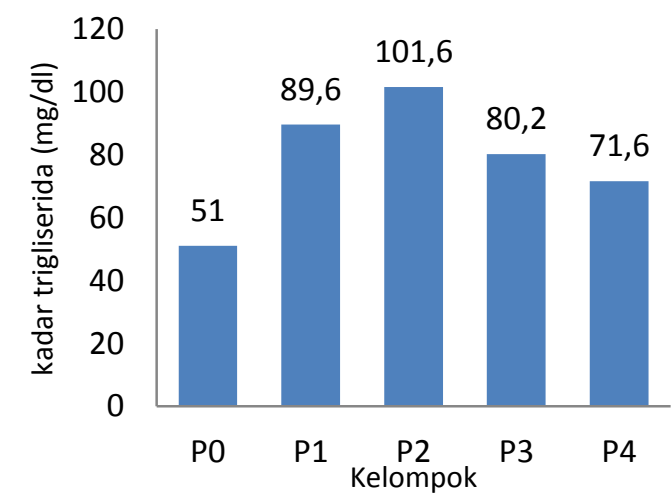

Gambar 1. Rata-rata kadar trigliserida tikus pada masing-masing kelompok (mg/dl).

Pada Gambar 1 diketahui bahwa pemberian diet aterogenik dapat meningkatkan rata-rata kadar trigliserida darah. Nilai tertinggi rata-rata kadar trigliserida darah ditunjukkan pada kelompok P2 dengan diet aterogenik dan tepung ilesiles kuning 0,13 g/hari, yaitu 101,60 $\pm 23,73$ $\mathrm{mg} / \mathrm{dl}$. Sementara itu, rata-rata kadar trigliserida terendah ditunjukkan pada kelompok PO dengan diet normal, yaitu $51 \pm 4,74 \mathrm{mg} / \mathrm{dl}$. Penurunan kadar trigliserida darah yang berkesinambungan diketahui pada kelompok perlakuan yaitu pada kelompok P2 dengan diet aterogenik dan tepung iles-iles kuning 0,13 g.hari, P3 dengan diet aterogenik dan tepung iles-iles kuning 0,30 g/hari, dan P4 dengan diet aterogenik dan tepung iles-iles kuning 0,60 g/hari.

Berdasarkan uji Shapiro Wilk menunjukkan bahwa data terdistribusi secara normal yaitu $p>0,05$ dan hasil test of homogenity of variance menunjukkan bahwa data menunjukkan hasil yang homogen yaitu $p>0,05$. Untuk hasil uji statistik one way ANOVA dengan tingkat kepercayaan $95 \%$ ( $p$ $<0,05$ ) menunjukkan bahwa rata-rata kadar trigliserida tikus antar kelompok perlakuan menunjukkan hasil yang signifikan yaitu $p<$ $0,05(p=0,017)$. Setelah diketahui adanya perbedaan yang signifikan, maka dilakukan uji statistik post hoc Tukey untuk mengetahui adanya perbedaan antar kelompok. Kelompok P0 berbeda secara signifikan dengan kelompok P2. Pada kelompok P1 tidak berbeda secara signifikan dengan kelompok P0, P2, P3, dan P4. Lalu pada kelompok P2 diketahui berbeda signifikan dengan kelompok P0. Pada kelompok P3 diketahui tidak berbeda secara signifikan dengan kelompok P0, P1, P2, dan P4. Sementara itu, pada kelompok P4 menunjukkan tidak berbeda secara signifikan dengan kelompok P0, P1, P2, dan P3.

Jadi dapat disimpulkan bahwa kadar trigliserida darah antara kelompok kontrol negatif (PO) dengan kelompok perlakuan (P2, P3, dan P4) terdapat perbedaan yang signifikan. Sedangkan antara kelompok kontrol positif (P1) dengan kelompok perlakuan (P2, P3, dan P4) tidak terdapat perbedaan yang signifikan.

\section{Pembahasan}

Asupan Makanan:

Pada penelitian ini diet yang diberikan adalah secara isokalori yaitu pakan yang diberikan dalam jumlah energi yang sama 104,6 kkal per hari. Penggunaan diet dengan cara isokalori telah ditetapkan untuk mencegah terjadinya bias pada hasil penelitian karena pengaruh energi yang diberikan kepada hewan coba berbeda.

Komposisi zat gizi pada pakan normal yang diberikan dengan berat $30,5 \mathrm{~g} / \mathrm{hari}$ mengandung energi sebesar 104,6 kkal, protein $21,28 \%$ dari total energi atau sebesar 
5,56 gram, lemak $9,71 \%$ dari total energi atau sebesar 1,13 gram, dan karbohidrat $61,43 \%$ dari total energi atau sebesar 3,97 gram. Sedangkan untuk komposisi zat gizi dari diet aterogenik yang diberikan dengan berat $25 \mathrm{~g} /$ hari mengandung energi sebesar 104,6 kkal, protein $13,59 \%$ dari total energi atau sebesar 3,54 gram, lemak $34,3 \%$ dari total energi atau sebesar 3,97 gram, dan karbohidrat $52,14 \%$ dari total energi atau sebesar 13,58 gram.

Berdasarkan uji statistik one way ANOVA menunjukkan bahwa tidak ada perbedaan yang signifikan yaitu $p>0,05(p$ $=0,188$ ) terhadap rata-rata asupan energi pada kelima kelompok perlakuan. Untuk rata-rata asupan karbohidrat, protein, dan lemak menunjukkan adanya perbedaan yang signifikan pada kelima kelompok perlakuan. Hal ini menggambarkan keadaan dislipidemia pada tiap kelompok adalah berbeda karena perbedaan asupan lemak pada setiap kelompok perlakuan.

Pengaruh Diet Aterogenik terhadap Kadar Trigliserida Darah Tikus:

Penelitian ini menggunakan diet aterogenik untuk mengondisikan tikus dalam keadaan dislipidemia, yang salah satunya ditandai dengan peningkatan kadar trigliserida. Nilai rata-rata kadar trigliserida darah yang tertinggi ditunjukkan pada kelompok P2 dengan diet aterogenik dan tepung iles-iles kuning 0,13 g/hari, yaitu $101,60 \pm 23,73 \mathrm{mg} / \mathrm{dl}$. Sedangkan rata-rata kadar trigliserida terendah ditunjukkan pada kelompok P0 dengan diet normal, yaitu $51 \pm$ $4,74 \mathrm{~g} / \mathrm{dl}$.

Berdasarkan uji statistik one way ANOVA, menunjukkan adanya perbedaan yang signifikan yaitu $p<0,05(p=0,017)$ pada rata-rata kadar trigliserida. Perbedaan yang signifikan ini disebabkan karena ratarata jumlah asupan lemak pada tiap kelompok perlakuan berbeda-beda. Selain itu, nilai tertinggi rata-rata asupan lemak ditunjukkan pada kelompok P1 dengan diet aterogenik yaitu $4,74+0,85 \mathrm{~g} / \mathrm{hari}$ dari total pakan yang diberikan dalam sehari. Sedangkan rata-rata asupan terendah ditunjukkan pada kelompok P0 dengan diet normal yaitu 1,11 $\pm 0,23 \mathrm{~g} / \mathrm{hari}$. Berdasarkan uji statistik one way ANOVA menunjukkan adanya perbedaan yang signifikan yaitu $p<$ $0,05(p=0,000)$ pada rata-rata asupan lemak pada hewan coba.

Pengaruh Tepung lles-iles Kuning terhadap Kadar Trigliserida Darah Tikus:

Pada penelitian ini, pemberian tepung iles-iles kuning bersamaan dengan diet aterogenik menggunakan dosis sesuai kebutuhan yang disarankan untuk manusia, kemudian dikonversikan berdasarkan tabel sesuai kebutuhan tikus. Kemudian disesuaikan dengan rata-rata berat badan awal tikus pada masing-masing kelompok, sehingga didapatkan dosis 0,13 $\mathrm{g} / 200 \mathrm{gBB} /$ hari untuk kelompok P2, 0,30 $\mathrm{g} / 200 \mathrm{gBB} /$ hari untuk kelompok $\mathrm{P} 3$, dan 0,60 $\mathrm{g} / 200 \mathrm{gBB} /$ hari untuk kelompok P4.

Pemberian tepung iles-iles kuning bersamaan dengan diet aterogenik pada penelitian ini, tidak menunjukkan adanya efek pencegahan peningkatan kadar trigliserida darah pada tikus. Hal ini berdasarkan kadar trigliserida darah pada kelompok P1 yaitu $89,60 \pm 28,43 \mathrm{mg} / \mathrm{dl}$ yang lebih rendah dibandingkan dengan kelompok P2 yaitu 101,60 $23,73 \mathrm{mg} / \mathrm{dl}$. Pada kelompok P4 diketahui kadar trigliserida paling rendah yaitu $71,60 \pm 27,32$ $\mathrm{mg} / \mathrm{dl}$ dibandingkan dengan kelompok P3 yaitu $80,20 \pm 14,20 \mathrm{mg} / \mathrm{dl}$ dan kelompok P2

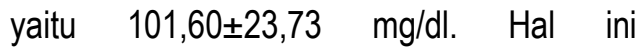
menunjukkan bahwa semakin tinggi dosis tepung iles-iles yang diberikan maka semakin efektif dalam mencegah peningkatan kadar trigliserida darah.

Glukomanan dapat menurunkan kadar trigliserida dengan cara serat di dalam usus akan mengikat asam lemak sehingga 
menghambat penyerapan asam lemak yang akhirnya menghambat pembentukan trigliserida, karena trigliserida terbentuk dari 3 asam lemak, sehingga peningkatan kadar trigliserida darah dapat dicegah. ${ }^{10}$

Pada penelitian ini diketahui dalam 100 gram tepung iles-iles kuning mengandung $33 \%$ glukomanan. Selain itu, tepung iles-iles kuning dengan hasil analisis mengandung zat gizi lemak mencapai $0,04 \%$ dalam 100 gram tepung iles-iles kuning. Berdasarkan uraian di atas menunjukkan tepung iles-iles kuning tidak terbukti dapat mencegah peningkatan kadar trigliserida darah tikus yang diberikan diet aterogenik.

\section{Kesimpulan}

Pemberian tepung iles-iles kuning (Amorphophallus oncophyllus Prain) tidak terbukti dapat mencegah peningkatan kadar trigliserida pada tikus yang diberikan diet aterogenik Semakin tinggi dosis tepung ilesiles kuning yang diberikan maka semakin baik dalam mencegah peningkatan kadar trigliserida darah tikus yang diberikan diet aterogenik.

\section{Saran}

1. Perlu dilakukan penelitian lebih lanjut tentang efek pemberian tepung iles-iles kuning dengan dosis tinggi bila perlu dilakukan uji toksisitas terlebih dahulu terhadap pencegahan peningkatan kadar trigliserida darah tikus dengan diet aterogenik.

2. Perlu dilakukan alternatif lain dalam cara pemberian tepung iles-iles kuning ke tikus selain dengan cara sonde yaitu dengan cara ekstrak glukomanan, karena tepung iles-iles kuning mudah menggumpal dan apabila dosis yang diberikan terlalu tinggi sulit untuk melewati jarum sonde.

\section{Daftar Pustaka}

1. Hernawati. Peranan Berbagai Sumber Serat dalam Dinamika Kolesterol pada Individu Hiperkolesterolemia dan Normokolesterolemia. Bandung: Jurusan Pendidikan Biologi UPI. 2007.

2. Majid A. Penyakit Jantung Koroner Patofisiologi Pencegahan dan Pengobatan Terkini. Medan: Universitas Sumatra Utara. 2007.

3. Supriyono M. Faktor-Faktor yang Berpengaruh terhadap Kejadian Penyakit Jantung Koroner Pada Usia $\leq 45$ Tahun. Semarang: Universitas Diponegoro. 2008.

4. Anwar TB. Dislipidemia sebagai Faktor Resiko Penyakit Jantung Koroner. Tugas Akhir. Medan: Fakultas Kedokteran Universitas Sumatra Utara. 2004.

5. Kamso S. Nutrition Aspect of Hypertension in the Indonesian Elderly: A Community Study in 6 Big Cities. Jakarta: Universitas Indonesia. 2002.

6. Wahyuni T. Pengaruh Pemberian Juice Pare (Momordica charantia) terhadap Kadar Trigliserida Darah pada Tikus Putih yang Diberi Diet Aterogenik. Tugas Akhir. Malang: Fakultas Kedokteran Universitas Brawijaya. 2010.

7. Firmansyah F. Glukomanan. 2010. (Online). http://glukomanan.html/.

8. Harijati N, Rodliyati A, Widyarti S. Eksplorasi Amorphophallus sp Endemik Jawa Timur yang Tinggi Glukomanan dan Rendah Alergenitasnya. Malang: Fakultas Matematika dan IImu Pengetahuan Alam Universitas Brawijaya. 2002.

9. Adji TB. SCADA (Supervisory Control and Data Acquisition) Menggunakan Teknologi Komunikasi Bergerak. Yogyakarta: Universitas Gadjah Mada. 2005. 
10. Kotiah U. Pengaruh Pemberian Ekstrak Lidah Buaya terhadap Kadar Kolesterol HDL dan LDL Serum Tikus Puth Hiperkolesterolemi. Tugas Akhir. Semarang: Universitas Negeri

Semarang. 2007. 